\title{
DEMOCRATIC POLITICAL SYSTEM \\ IN THE PERSPECTIVE OF MAQASID SHARIA : STUDY ANALYSIS OF YUSUF AL-QARADAWI'S THOUGHT
}

\author{
Athoilah Islamy \\ Institut Agama Islam Negeri Pekalongan \\ Jalan Kusuma Bangsa No.9 Panjang Baru, Jawa Tengah \\ Email: athoillahislamy@yahoo.co.id \\ Sansan Ziaul Haq \\ Institut Teknologi Bandung \\ Jalan Ganesha No.10, Lb. Siliwangi, Kota Bandung, Jawa Barat \\ Email: Ziaulhaqsansan25@gmail.com
}

\begin{abstract}
Islam and politics is how legitimate the democratic political system is in the paradigm of Islamic law. This study will explain the alternative paradigm in evaluating the democratic system based on the paradigm of Islamic law from a prominent Muslim intellectual named Yusuf al-Qaradawi. This research is a qualitative research in the form of literature review. The primary source used is a variety of literature that explains Yusuf al-Qaradawi's thoughts about democracy in Islam. The method used is the method of interpreting the thoughts of the figures with the maqasid al-shari 'ah approach. There are two big conclusions of this research. First, Yusuf al-Qaradawi's view of democracy can be said to be grounded in its epistemological foundation in understanding the concept of an Islamic state. For al-Qaradawi, an Islamic state is a system of government that provides policy improvisation space in the benefit of social, economic and political life based on the objectives of Islamic law (maqasid shari'ah). Second, Yusuf al-Qaradawi's view, the democratic system can be compatible with Islam if the principles in the democratic system are in accordance with various values which are the spirit of the objectives of Islamic law (maqasid shari'ah), such as the value of justice, equality of rights, freedom, etc. so. To realize this, the democratic system must carry a holistic vision and mission, which includes worldly and ukhrawi benefits as well as individual and social benefits.
\end{abstract}

Keywords: Validity, democracy, Yusuf al-Qaradawi, maqasid shari'ah;

\begin{abstract}
Abstrak: Salah satu isu besar yang masih debatable tentang relasi Islam dan politik adalah bagaimana keabsahan sistem politik demokrasi dalam paradigma hukum Islam. Penelitian ini akan menjelaskan paradigma alternatif dalam menilai sistem demokrasi berdasarkan paradigma hukum Islam dari seorang intelektual muslim terkemuka yang bernama Yusuf al-Qaradawi. Adapun penelitian ini merupakan penelitian kualitatif yang berupa kajian pustaka. Sumber primer yang digunakan adalah berbagai literatur yang menjelaskan pemikiran Yusuf al-Qaradawi tentang demokrasi dalam Islam. Metode yang digunakan adalah metode interpretasi pemikiran tokoh dengan pendekatan maqasid al-shari 'ah. Terdapat dua kesimpulan besar penelitian ini. Pertama, pandangan Yusuf al-Qaradawi tentang demokrasi dapat dikatakan berpijak pada landasan epistemologinya dalam memahami konsep negara Islam. Bagi alQaradawi, negara Islam merupakan sistem pemerintahan yang memberikan ruang improvisasi kebijakan dalam kemaslahatan kehidupan sosial, ekonomi dan politik dengan berlandaskan tujuan-tujuan hukum Islam (maqasid shari'ah). Kedua, pandangan Yusuf al-Qaradawi, sistem demokrasi dapat kompatibel dengan Islam jika prinsip dalam sistem demokrasi sesuai dengan berbagai nilai yang menjadi spirit tujuan hukum Islam (maqasid al-shari 'ah), seperti nilai keadilan, persamaan hak, kebebasan, dan lain sebagainya. Untuk mewujudkan hal tersebut, maka sistem demokrasi harus memebawa visi dan misi yang holistik, yakni mencakup kemaslahatan duniawi dan ukhrawi serta kemaslahatan individual dan sosial.
\end{abstract}

Kata kunci : Keabsahan, demokrasi, Yusuf al-Qaradawi, maqasid shariah; 
AL-IMARAH: Jurnal Pemerintahan dan Politik Islam

Vol. 5, No. 1, 2020

\section{Introduction}

The phenomenon of the political system movement in the 20 th century was dominated by the democratic political system. This is due to the bargaining power of the democratic system which gives the government power to the people, so that the direction of government policy can easily present the people's aspirations. ${ }^{1}$ In this regard, Robert A. Dahl states that the modern democratic political system has guaranteed human rights, recognizes individual freedom, equal political rights, protects, realizes peace and prosperity. ${ }^{2}$ Thus it can be understood logical reasons why the democratic political system can be accepted by various modern countries because democracy promises various consequences that benefit the people, because this system will automatically avoid various forms of tyranny and despotism in state life.

Although it has become a political system that is widely applied in various countries, the existence of a democratic political system in its relationship with Islam has generated debate, both among Muslim and non-Muslim intellectuals, namely the status of the validity of the democratic political system within the Islamic paradigm. For secular circles, Islam as a religion is the most personal

\footnotetext{
Rene Klaff, "Prinsip-prinsip Dasar Demokrasi dan Pemerintahan yang Baik," dalam Islam dan Barat : Demokrasi dalam Masyarakat Islam, ed. Ulil Abshar Abdalla (Jakarta: Paramadina, 2002), h. 109-110.

2 Robert A. Dahl, On Democracy (Virginia: Yale University, 1998), h. 44-45 56
}

expression of faith, and cannot be translated into a political system or regulation. Islam is a religion that is limited only to the vertical relationship between an individual and his God. ${ }^{3}$ This statement is different from the opinion of other circles who state that Islam is a way that not only regulates how to deal with the vertical relationship with God, but also horizontal relations with fellow humans in various aspects of life, such as social life, economics, politics, culture and so forth. ${ }^{4}$ From this it can be understood that the point of dispute between the two different views above is due to differences in the paradigm of the existence of Islam in the context of life.

In this study, the author will analyze one of the thoughts of the world's Islamic legal leaders, namely Yusuf al-Qaradwi about the validity of a democratic political system in Islam. Through the maqasid shariah paradigm, the writer will try to elaborate on the substance of al-Qaradawi's thinking about the validity of the democratic political system in the paradigm of Islamic law.

\section{Paradigm Shift In The Democracy: From}

\section{Liberal Democracy to Social Democracy}

Discussing the relationship between democracy and liberalism in the political system, Francis Fukuyama explained that liberal democracy as a rule of law that recognizes certain individual rights of

3 Abdullah Saeed, Islamic Thought: an Introduction (New York: Routledge, 2006), h. 125.

${ }^{4}$ Ron Geaves, Aspects of Islam,' Review by: Connie Lamb, MELA Notes , No. 81 (2008), h. 104106. 
government control, such as civil rights, religious rights and political rights. For Fukuyama, a country is said to be democratic if it gives the people the right to determine their own government through a periodic election, and to be held honestly and fairly. ${ }^{5}$ This liberal democracy then after the cold war became the only system of government that was considered the most ideal and promised the realization of good governance. This is supported by the fact that many countries from all corners of the world are carrying out the process of democratization in the style of the United States prototype. ${ }^{6}$ The victory of the United States and its allies over the Soviet Union had a great influence on other developing countries, to imitate their style of state and rule. $^{7}$

Even though history has brought achievements, the existence of liberal democracy is inseparable from various controversies. Liberal conceptions are considered responsible for various social and humanitarian tragedies. The negative implication of liberal democracy is precisely injustice and socio-economic inequality for the ordinary people. ${ }^{8}$ In this case, Thomas Meyyer

${ }^{5}$ Francis Fukuyama, The End of History and The Last Man (New York: The Free Press, 1992), h. 4243.

6 Sylvia Chan, Liberalism, Democracy and Development (Cambridge: Cambride University Press, 2002), h. 11.

${ }^{7}$ William E. Scheuerman, Liberal Democracy and the Empire of Speed,' Polity, Vol. 34, No. 1 (Autumn, 2001), h. 42.

${ }^{8}$ Isham Suliman, al-Dimuqratiyyah, h. 24. argues that although liberal democracy guarantees state justice in the constitutional corridor, some social and economic conditions are still regarded as private areas that are free from intervention and structure. According to Meyyer, various anomalies in liberal democracy are basically a series of violations of human rights. human rights. First, in the social and economic sphere, this system results in large gaps in opportunities and choices for the lower classes of society. On average, small people do not have the social means to live properly. Second, many poor people whose minds and energy are drained to meet economic and social needs, so that marginalized from most of the social and cultural life of a decent society. Third, liberal democracy is essentially elitist democracy, because only large groups can actually use democratic civil rights. While on marginal parties, life dependency and economic needs make them easily influenced and utilized by large groups. ${ }^{9}$

Various anomalies as above require various improvements to the mechanism of democracy. Democracy is demanded to be more able to guarantee social balance and protect human rights. It was this background that later gave birth to the offer of social democracy as a correction to the format of previous democracy. Basically, the format of

9 Thomas Meyyer, Demokrasi sosial dan Libertatian: Dua Model yang Bersaing dalam Mengisi Kerangka Demokras $i$ Liberal (Jakarta: FriedrichEbert-Stiftung (FES), 2012), h. 10-12. 
social democracy starts from the 1996 United Nations Basic Rights Convention (United Nations Covenants on Basic Rights 1996). This document mentions five human rights: civil, political, social, economic and cultural rights. According to Moyyer, liberal democracy only guarantees the first two rights, namely civil rights, such as freedom of opinion and freedom of association, and political rights, such as the right to form political parties and the right to vote. Meanwhile, social, economic and cultural rights that have the same level of urgency and validity are not the concern of the government. This is different from social democracy which guarantees the realization of social justice for all people, regardless of their social status or wealth. Countries that make social democracy their political system will be more involved in efforts to realize social welfare comprehensively. The state will intervene in various market mechanisms for the realization of economic success and growth, as the state will contribute actively in improving various aspects of people's lives in order to realize social cohesion and political stability. ${ }^{10}$

From the above explanation it can be concluded that the existence of a social democratic system is a new paradigm shift in the democratic system to create a better political system. This shows that as a political system, democracy is a work of human

10 Thomas Meyyer, Demokrasi sosial dan Libertatian: Dua Model yang Bersaing dalam Mengisi Kerangka Demokras i Liberal, h. 13-16. 58 creativity that is dynamic, both from the formalistic and substantialistic aspects. Thus, substantially, democracy as a product of political thought can be integrated with various ideologies and religious teachings, including Islamic teachings.

\section{Discourse on the Relationship between Democracy and Islam}

The paradigm of the relationship between Islam and democracy gave birth to a variety of different views among Muslim and non-Muslim intellectuals who study Islamic studies. Not only are they different, but there are also those who oppose their views regarding the validity of the democratic system in Islam. Taqiyyudin al-Nabhani, founder of the Islamic Hizb ut-Tahrir organization, firmly rejects democracy in Muslim countries. For him, an Islamic state must not take a view of life or legal legislation system from outside the teachings of Islam. Democracy in this case cannot be accepted because it is a foreign ideology that is contrary to the principles of Islamic teachings. ${ }^{11}$ Furthermore, Said Abdul Azim stated that democracy is basically a government where the source of authority authority is in the hands of the people, both in terms of executive, judicial and legislative institutions. According to Said, this is clearly contrary to the teachings of Islam, because in Islam the authority to make various laws and

11 Taqiyyudin al-Nabhani, Nizam al-Hukmi fi al-Islam (Beirut: t.p., 1976), 18-19. 
regulations is God's prerogative. ${ }^{12}$ This was also stated by Muhammmad Ahmad Ali Mufti. According to him, democracy is essentially a system of government based on the separation of religion from the state. The principles of democracy are a secular system, because they make individuals the highest foundation in making legal decisions and various policies, so that they automatically deny the supremacy of religion in regulating aspects of life. ${ }^{13}$

Not only from Muslim intellectual figures, some Western scholars who are concerned in Islamic studies also doubt the possibility of achieving a meeting point between democracy and Islam. Francis Fukuyama argues that Islam is a cultural obstacle to Muslim countries for the process of democratization. This is because Islam is a religion whose teachings cover all aspects of human life. This basic character, according to Fukuyama, is very difficult to make peace with the demands of liberalism and the recognition of universal values, especially regarding the right to freedom of religion. So it's not surprising, Fukuyama added, if the only liberal democracy in the Muslim world is contemporary Turkey, which is the only country that has a connection with an explicit rejection of Islamic heritage and chose the form of secular society in the early 20th

\footnotetext{
${ }^{12}$ Said Abdul Azim, al - Dimuqratiyyah fi al Mizan (Iskandaria: t.p., t.t.), h. 41.

13 Muhammad Ahmad 'Ali Mufti, Naqd alJudur al-Fikriyyah li al-Dimuqratiyyah (Riyad, Maktabat al-Malik Fahd al-Wataniyyah, 2002), h. 105107.
}

century. ${ }^{14}$ Then, Samuel P. Huntington explains that among the dominant factors causing clash of civilizations are different cultural characteristics. Cultural and religious differences cause differences in the outlook on various issues, expansion of human rights, immigration matters, commercial trade and environmental issues. Most crucially, according to Huntington, western efforts in offering democratic values and liberalism as universal values with the aim of military dominance and economic interests have triggered a response to the rejection of other civilizations. Related to the relationship between the West and Islam, historical facts show that the conflict between the two civilizations has been going on for 1300 years. $^{15}$

In contrast to the paradigm of the intellectuals above who reject democracy as an Islamic government system, there are some Muslim intellectuals who disagree with the paradigm that rejects the democratic system. Nurcholish Majid (Cak Nur) believes that the election of democracy as an ideology of the State whose values within it is supported by the spirit Islamic teachings, this election is also based on consideration of the function of democracy as a rule of open political play, which accepts various corrections and

${ }^{14}$ Francis Fukuyama, The End of History and The Last Man (New York: The Free Press, 1992), h. 333-334.

15 Samuel P. Huntington, The Clash of Civilization?, Foreign Affairs, Vol. 72, No. 3 (Summer, 1993), h. 28-31. 
improvements. ${ }^{16}$ The normative foundation that affirms the positive relationship between Islam and democracy refers to a number of verses that talk about themes of monotheism, justice, deliberation, individual freedom and responsibility, freedom of experimentation, freedom of religion, and brotherhood. According to Cak Nur as quoted by Syamsuar Basyariah stated that these fundamental values require every individual Muslim to be able to operate it. ${ }^{17}$ When looking at the fact that Islamic teachings are loaded with universal values which are in line with the ideals of humanity and democracy on the one hand, and the fact that the majority of modern Islamic movements demand the participation of people in politics on the other hand, many Western scholars see the possibility of reconciliation between Western democracy and Islam. Jhon L. Esposito believes that the Islamic view is identical with democratic values. This is based on the fact that in Islamic teachings, there are a number of concepts and images about how an ideal society can be realized. These ideal values then become the basis for Islam in perceiving democracy. ${ }^{18}$ Within the conceptual framework of Islam, democracy is considered as a system that reinforces concepts that have long been rooted in the Islamic tradition,

${ }^{16}$ Nurcholish Majid, Cita - cita Politik Islam (Jakarta: Dian Rakyat, 2006), h. 44.

${ }^{17}$ Syamsuar Basyariyah, Integrasi Agama dan Negara: Paradigma Politik Nurcholish Madjid Era Orde Baru Tahun 1966 - 1998 (Yogyakarta: Kaukaba, 2010), h. 122.

${ }^{18}$ John L. Esposito, Demokrasi d i Negara Negara Muslim: Problem dan Prospek, terj. Rahmadi Astuti (Bandung: Penerbit Mizan, 1999), h. 27. 60 namely the concepts of shura, ijma '(consensus), and ijtihad. ${ }^{19}$ Dale Eickelman and James Piscatori through their book entitled Muslim Politics, argues the possibility of democratization of Muslim countries. In practice, Islamic politics involves competition and contests in terms of interpretation of religious symbols and control over formal and informal institutions, which support and sustain political actions themselves. Competition among Muslims regarding traditions, family issues, ethnicity, locus of spiritual authority, and the boundaries between politics and religion are objects of Muslim politics. In the modern context, social mobilization and improvement of human resources have increased the tension between religious and political divisions. For Eickelman and Piscatori, this disagreement and division can lead to sharper confrontations, conflicts and violence, but it also has a great opportunity to open the way to more plural and democratic forms of competition.. ${ }^{20}$

From the description above clearly visible epistemological differences in the intellectual circles in Islamic studies related to the validity of democracy as a political school

19 John L. Esposito, Demokrasi di Negara Negara Muslim: Problem dan Prospek, 32. Lihat juga John L. Esposito, ,Islam and Democracy, Review by: Roger Hardy, International Affairs (Royal Institute of International Affairs 1944-), Vol. 73, No. 2, Asia and the Pacific (Apr., 1997), h. 387-388

20 Dale F. Eickelman and James Piscatori, Muslim Politicse, Review by: Robert D. Lee, International Journal of Middle East Studies , Vol. 29, No. 4 (Nov., 1997), pp. h. 629-631 
of Islamic governance. For those who do not reject democracy as an Islamic political government system, they try to be productive in attracting the substance of democracy in Islam. argues that democracy cannot be said to be totally opposite to Islam. There are certain values of the concept of democracy that are in accordance with the principles of Islamic humanity. However, in the end, we must admit that democracy is not a final concept, just as interpretation of Islam never recognizes the word complete. Continuity of the dynamics of human life certainly also requires answers that must always be responded.

\section{Yusuf al-Qaradawi's Thoughts on Democracy in the Maqasid Sharia Perspective}

\section{Value Paradigm in Understanding the} Concept of the Islamic State

Before specifically studying Yusuf al-Qaradwi's views on democracy, in this section the writer will first analyze his views on the concept of an Islamic state. Thus alQaradawi's view of democracy can be said to rest on its epistemological foundation in understanding the concept of an Islamic state. According to al-Qaradawi, an Islamic state is basically a civil state as are most other countries. According to him, Islamic political thought did not recognize the term religious state as a form of theocracy known to the West in the dark ages. ${ }^{21}$ Therefore, it

21 Yusuf al-Qaradawi, al-Din wa al- Siasah (Kairo: Dar al-Shuruq, 2006), h. 158-192. can be understood that for al-Qaradawi the concept of an Islamic state is different from the concept of a theocratic state which makes religious leaders have authority as representatives of God in running the government system as has happened in the history of government in the Western world.

According to al-Qaradwi, conceptually the Islamic state stood on the belief of God's absolute authority. But this does not mean that an Islamic state is the same as a Western theocracy system. What is meant by God's absolute authority in Islamic politics is the authority to make Islamic law. While political authority is returned to the will of the people. So then, it is the people who choose the leader of the state freely, as well as those who control it. Al-Qaradawi further asserted that God's authority was limited to the realm of pure religious rules, such as matters of worship, halal-haram, various commands for doing good and various prohibitions on committing heinous acts, and certain forms of punishment. Aside from this realm, human beings are required to determine and formulate their own rules and laws that are considered the most useful. ${ }^{22}$ Yusuf al-Qaradawi stressed that the concept of an Islamic state must be better understood substantively so as not to

${ }^{22}$ Yusuf al-Qaradawi, al-Din wa al-Siasah, h. 166-170. 
get caught up in rigid symbolism. shari'ah as a vital elan of an Islamic state, must be understood holistically and deeply, so that it does not always connote horrible things such as cutting off hands, provoking and stoning. Substantification of shari'ah will see poverty alleviation, empowerment of women, human development as the main priority that must be realized. $^{23}$ alQaradawi's view is adaptable to the phenomenon of the positification of Islamic law in various countries which can be intervened by the dynamics of government policy politics, so that the form of product of positification of Islamic law can vary according to the social context of each country. ${ }^{24}$

From the above explanation it can be understood that the concept of an Islamic state for al-Qaradawi, is a system of government that provides a space for improvisation of policies in the benefit of social, economic and political life based on the objectives of the shari'ah (maqasid shari'ah). This is because in al-Qaradawi's view, which forms the basis of legitimacy in an Islamic state, are the objectives of Islamic law, not merely literalism of the text. Such understanding necessitates that in the substantial paradigm of the Islamic

${ }^{23}$ Yusuf al-Qaradawi, Min Fiqh al - Daulah fi al - Islam (Kairo: Dar al-Shuruq, 2001), h. 34.

24 Athoillah Islamy, "Eksistensi Hukum Keluarga Islam di Indonesia dalam Kontestasi Politik Hukum dan Liberalisme Pemikiran Islam", Al-Istinbath Jurnal Hukum Islam, Vol.4, No.2 (2019), h. 173-174. 62 state's consensus enable the formation of various political systems that are compatible with Islamic teachings, even though they do not use Islamic names or symbols, such as the adoption of a democratic system that historically was born as a Western political system.

\section{Making Democracy a Political System} That Brings the Mission Objectives of Islamic Law

Regarding the relationship between Islam and democracy, in the internal body of Islam there are two extremes that cross each other. First, groups who reject democracy totally. They base their views on several assumptions, including, that Islam is sourced from God, while democracy comes from pure human thought; democracy means the absolute authority of the people, whereas Islam is the pure authority of God; democracy is heresy and is a principle imported from the West. Second, those who accept democracy as a whole, with all its ideological content, include social liberalism, economic capitalism and absolute freedom. According to them, in order for the Muslim world to progress, we must imitate the West in every aspect of life and adopt their civilization, both sweet and bitter. ${ }^{25}$

In responding to the two trends

${ }^{25}$ Yusuf al-Qaradawi, al - Din wa al - Siasah, h. 175 
above, Yusuf al-Qaradawi criticized the first tendency. According to him, this tendency departs from ignorance related to certain values of democratic political systems that are in line with Islamic values, such as the concept of deliberation, political contracts, oath of allegiance to the people and others. ${ }^{26}$ As for the second tendency, al-Qaradawi also rejected it because of the form of Westernization efforts in the Islamic world. In this case, al-Qaradawi offers a reconciliative offer. According to al-Qaradawi, we need to have a moderate view and attitude, that is, not to accept or reject democracy totally. These moderate views and attitudes are in the context of adopting the essence of democracy in accordance with Islamic values. The essence of democracy for alQaradawi is that the people elect themselves the people who will lead them, rather than being forced to submit to authoritarian leaders or the despotic system and there is a right for the people to aspire to votes and criticism of government policies. ${ }^{27}$ Qaradawi's view is thus in line with the various objectives of Islamic law (maqasid shariah) which uphold human freedom for the realization of the benefit of life, both in the context of religious which is ukhrowi and in the

${ }^{26}$ Yusuf al-Qaradawi, Min Fiqh al - Daulah fi al-Islam, h. 130-137. 175. context of worldly states. According to Sahtibi, the main level of benefit is the goal of Islamic law, namely the benefits of daruriat. The benefit at this level is the basic benefit that must exist in order to realize the benefit for life, both in this world and the hereafter. Vice versa, if there is no, there will be damage to him, both in the world and the hereafter. Shatibi explained that there were five objectives of Islamic law at this level, namely guarding religion (hifz al-din), guarding the soul (hifz al-nafs), guarding offspring (hifz al-nasl), protecting property (hifz almal), and guarding reason (hifz al-'aql). ${ }^{28}$ Thus it can be concluded that besides giving the right of freedom in the five objectives of Islamic law, in the context of state life implementing a democratic system there must be an active role of government policy, so that the democratic system can be compatible with various objectives in Islamic law.

For al-Qaradawi, the basic standard in the realm of pure religion is to follow the tradition of tradition, but what is the basis of worldly affairs is creation and innovation. The universality of Islam does not mean that the teachings of Islam are final, so we only need to apply them to the reality of life. What is permanent and eternal about Islam are matters relating to

${ }^{28} \mathrm{Abu}$ Ishaq al-Shatibi, al-Muwafaqot fi Usul al-Shari'ah, h. 8-12. 
faith, pure worship, values and morality, and certain laws Besides that realm, unlimited space will remain wide open to the process of ijtihad and human thinking. ${ }^{29}$ Such a view is in line with the paradigm of the maqasid shariah which requires a typology of universal benefit (al-maslahat al-kulliat), namely benefit for all humans. Second, partial problems (al-maslahat aljuz'iat), which are benefits for some of humanity. ${ }^{30}$ From this it can be understood alQaradawi's view in the context of the paradigm of the Islamic political system is more directed at the partial aspect by providing a space for thinking ijtihad of thought for humans.

According to al-Qaradawi, democracy as a system of government is instrumental and operational, so the good and bad parameters do not lie in themselves, but on whether the system and form of government is able to negotiate the core objectives of shari'ah or not. As long as a system is able to realize these objectives, we will punish that the system is in accordance with shari'ah. The main objectives of shari'ah in social life according to al-Qaradawi are justice, brotherhood, social solidarity. ${ }^{31}$ Even if we say that democracy as an ideology is the result of human thought in the context of

${ }^{29}$ Yusuf al-Qaradawi, al-Din wa al Siasah, h. 123-126.

${ }^{30}$ Ahmad Sarwat, Maqasid Shariah, (Jakarta : Rumah Fiqh Publishing, 2019), h. 55-56.

${ }^{31}$ Yusuf al-Qaradawi, Madkhal li Dirasat alShari'ah al-Islamiyyah (Kairo: Maktabah Wahbah, 2011), h. 66.
Western culture, we cannot punish everything that is human in nature as despicable. The thing that cannot be denied is that religion is not entirely divine. There are certain aspects that demand human involvement in order to interpret, implement and actualize religious values into reality. How not, added al-Qaradawi, while God himself instructed us to use our minds to think, emulate and take lessons. According to al-Qaradawi, what can be adopted from democracy are various mechanisms and forms of guarantee offered in the government system, not his philosophical understanding that glorifies individualism over communal interests and adheres to absolute freedom without moral restrictions. ${ }^{32}$ Al-Qaradawi's view which is flexible in addressing the democratic system as a product of human thought that can realize the benefit of human life is in line with the Shatibi maqasid paradigm which explains that to realize the benefit of Islamic law can be through protection from two aspects. Protection from the two aspects referred to, namely protection in terms of its existence (min janib al-wujud) and protection in terms of its absence ( $\mathrm{min}$ janib al-'adam). ${ }^{33}$ Thus it can be understood that in order to obtain the benefit of Islamic law in the context of state

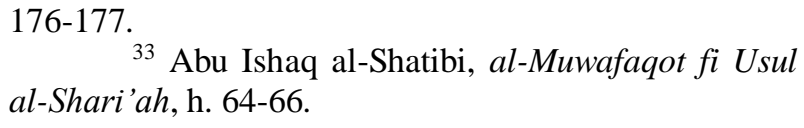
176-177.

${ }^{33}$ Abu Ishaq al-Shatibi, al-Muwafaqot fi Usul al-Shari'ah, h. 64-66.

${ }^{32}$ Yusuf al-Qaradawi, al-Din wa al-Siasah, h. 
life, the existence of democracy can be said as a medium in realizing it. Yusuf alQaradawi's view of the existence of democracy in Islam can be said to be a substantialistic view. He does not judge democracy from the historical aspect which is a product of political thought born from the non-Islamic world. $\mathrm{He}$ further considered democracy as a political system that can run in accordance with Islamic teachings as long as its implementation does not conflict with Islamic teachings.

\section{Conclussion}

There are two big conclusions in this research. First, al-Qaradawi's view of democracy can be said to be grounded in its epistemological foundation in understanding the concept of an Islamic state. For alQaradawi, an Islamic state is a system of government that provides policy improvisation space in the benefit of social, economic and political life based on the objectives of Islamic law (maqasid shari'ah). Such understanding necessitates that a substantial paradigm of the concept of an Islamic state enables the formation of a variety of political systems that are compatible with Islamic teachings, as in the democratic system. Secondly, Yusuf alQaradawi's view of the dampness of the democratic system in Islam can be seen through the paradigm of the maqasid shariah. In the maqasid shariah paradigm, al-Qaradawi assesses that a democratic system can be compatible with Islamic values as long as the principles in a democratic system are in accordance with various values which are the spirit of the objectives of Islamic law (maqasid al-shari'ah), such as the value of justice, equality of rights, freedom, and so on. To realize this, the democratic system must carry a holistic vision and mission, which includes worldly and ukhrawi benefits as well as individual and social benefits. From this statement it can be understood that in substance, democracy as a political system that is widely used by various modern countries, both the majority and minority of the population is Muslim can still be said in accordance with Islamic teachings as long as the vision and mission in the democratic system is not contrary to the spirit of the legal objectives Islam (maqasid al-shariah).

\section{References}

Ahmad, Muhammad 'Ali Mufti, Naqd alJudur al-Fikriyyah li-alDimuqratiyyah, Riyad, Maktabat alMalik Fahd al-Wataniyyah, 2002.

al-Nabhani, Taqiyyudin, Nizam al-Hukmi fi al-Islam, Beirut:, 1976

al-Qaradawi, Yusuf, al-Din wa al-Siasah, Kairo: Dar al-Shuruq, 2006

al-Qaradawi, Yusuf, Min Figh al - Daulah fi al-Islam, Kairo: Dar al-Shuruq, 2001.

al-Qaradawi, Yusuf, Madkhal li Dirasat alShari'ah al-Islamiyyah, Kairo: Maktabah Wahbah.

Azim, Said Abdul, al-Dimuqratiyyah fi alMizan, Iskandaria.tp.tt.

A, Dahl, Robert, On Democracy, Virginia: Yale University, 1998.

Basyariah, Syamsuar, Integrasi Agama dan Negara: Paradigma Politik Nurcholish Madjid Era Orde Baru Tahun 19661998,Yogyakarta: Kaukaba, 2010. 
Chan, Sylvia, Liberalism, Democracy and Development,Cambridge: Cambride University Press, 2002.

Dale F. Eickelman and James Piscatori, Muslim Politics' Review by: Robert D. Lee, International Journal of Middle East Studies, Vol. 29, No.4,1997.

E, William Scheuerman, Liberal Democracy and the Empire of Speed, Polity, Vol. 34, No. 1 (Autumn, 2001)

Esposito, John L, Demokrasi di NegaraNegara Muslim: Problem dan Prospek, terj. Rahmadi Astuti Bandung: Penerbit Mizan, 1999

Esposito, John L ,Islam and Democracy, ${ }^{\circ}$ Review by: Roger Hardy, International Affairs, Royal Institute of International Affairs 1944-), Vol. 73, No. 2, Asia and the Pacific, 1997.

Fukuyama, Francis, The End of History and The Last Man, New York: The Free Press, 1992.

Geaves, Ron ,Aspects of Islam, Review by: Connie Lamb, MELA Notes, No. 81, 2008.

Huntington, Samuel P, The Clash of Civilization and the Remaking of World Order,New York: Simon and Schuster, 1996.

Isham, Sulaiman, al-Dimuqratiyah, Kairo: al-Markaz al-Alami li Dirasat wa Abhat al-Kitab al-Ahdar, 1988.

Ishaq, Abu al-Shatibi, al-Muwafaqot fi Usul al-Shari'ah.

Islamy, Athoillah,"Eksistensi Hukum Keluarga Islam di Indonesia dalam Kontestasi Politik Hukum dan Liberalisme Pemikiran Islam," Al-Istinbath : Jurnal Hukum Islam, Vol.4, No.2 (2019).

Sarwat, Ahmad,Maqasid Shariah,Jakarta : Rumah Fiqh Publishing, 2019.

Saeed, Abdullah, Islamic Thought: an Introduction, New York: Routledge, 2006.

Klaff, Rene "Prinsip-prinsip Dasar Demokrasi dan Pemerintahan yang Baik," dalam Islam dan Barat : Demokrasi dalam Masyarakat Islam, ed. Ulil Abshar Abdalla Jakarta: Paramadina, 2002.

Meyyer, Thomas, Demokrasi sosial dan Libertatian: Dua Model yang Bersaing dalam Mengisi Kerangka Demokras $i$ Liberal, Jakarta: Friedrich-EbertStiftung, 2012.

Majid, Nurcholis, Cita - cita Politik Islam, Jakarta: Dian Rakyat, 2006. 